\title{
The 2017 Life Achievement Awards of the International Sol-Gel Society
}

\section{Andrei Jitianu ${ }^{1,2}$}

Published online: 21 December 2018

(c) Springer Science+Business Media, LLC, part of Springer Nature 2018

The Life Achievement Award has been presented since 2005 to renowned researchers in recognition of a lifetime of outstanding contributions to the field of Sol-Gel Science and Technology. This award is conferred every other year during the International Sol-Gel Conference. The recipient of this prestigious award is selected based on an established procedure that reviews the nominees and their overall contribution to the field. The following list (Table 1) of awardees attests to the distinction of this award.

For this award cycle, the Board of Directors of the International Sol-Gel Society (ISGS) took into consideration the nomination of ten renowned sol-gel scientists. After the deliberations and voting, the board selected two scientists for the 2017 Life Achievement Award: Dr. Lisa C Klein (Fig. 1) who is a Distinguished Professor in the Department of Materials Science and Engineering at Rutgers, The State University of New Jersey and to Dr. C Jeffrey Brinker (Fig. 2) who is a Distinguished and Regent's Professor of Chemical and Biological Engineering and Molecular Genetics and Microbiology at the University of New Mexico.

The 2017 Life Achievement Award of the ISGS was special from two perspectives. For the first time this award was:

1. Granted to a woman (Professor Lisa C Klein).

2. Presented simultaneously to a Ph.D. advisor (Professor Lisa C Klein) and to her former student (Professor C Jeffrey Brinker).

Andrei Jitianu

ANDREI.JITIANU@1ehman.cuny.edu

1 Department of Chemistry, Lehman College-CUNY, Davis Hall, 250 Bedford Park Boulevard West, Bronx, NY 10468, USA

2 Chemistry and Biochemistry PhD Programs, The Graduate Center of the City University of New York, 365 Fifth Avenue, New York, NY 10016-4309, USA

\section{Dr. Lisa C Klein}

She graduated with her S.B. degree in Metallurgy (1973) and received the Ph.D. in Ceramics from the Department of Materials Science and Engineering (1977) from Massachusetts Institute of Technology. She joined Rutgers University in 1977. Presently, she is a Distinguished Professor in the Department of Materials Science and Engineering at Rutgers University. Her research interests lie in the area of sol-gel science, as a low-temperature process for making glass and ceramics. Her research specifically focuses on processing, on forming gels for optical applications, porous membranes, and electrochemical devices such as fuel cells, smart windows, and hermetic seals. Dr. Klein has five shared patents covering sol-gel processing for window coatings that help keep buildings warm in the winter and cool in the summer, a sol-gel fiber used in fluorescing, and a sol-gel coating for an oxygen concentrator. She is currently conducting research on anti-corrosion coatings for steel and other metals. Between 1993 and 2010, she was one of the original co-Editors of the Journal of Sol-Gel Science and Technology. Since 1998 she has been one of the Editors of Journal of the American Ceramic Society. In addition, she is a co-Editor of the Second Edition of the "Handbook of SolGel Science and Technology Processing Characterization and Applications" published in June 2018 by Springer [1] (Fig. 3).

Besides being a scientist, she is known for her many outreach activities. Dr. Klein was the first female faculty member in her Department and the School of Engineering at Rutgers University. She was the first woman elevated to the Distinguished Professor status in the School of Engineering, led the materials science and engineering graduate program for many years, and served two terms as president of the Rutgers AAUP-AFT union. 
Here are some highlights of Professor Klein's career:

- 2018-Faculty of the Year, School of Engineering, Rutgers University.

- 2018-Toledo Glass and Ceramic Award, Michigan/ Northwest Ohio Section, American Ceramic Society.

- 2017-Life Achievement Award of the ISGS, Liege, Belgium (Fig. 4).

- 2016-Fellow of the Society of Glass Technology.

- 2015-Human Dignity Award from Rutgers University.

- 2012-Member of the World Academy of Ceramics.

- 2001-Fellow of the New York Academy of Sciences.

- 1998-Achievement Award, Society of Women Engineers.

On September 7, 2017, the Life Achievement Award was presented to Dr. Klein in a ceremony (Fig. 4) which took place during the XIX International Sol-Gel Conference held in Liege, Belgium, September 3-8, 2017. The awardee presented a plenary lecture. Her contribution entitled "Applications of melting gels" can be found in this special issue.

\section{Dr. C Jeffrey Brinker}

He graduated with his B.S. (1972), M.S. (1975) in Ceramic Science and he received the Ph.D. in Ceramic Science (1979) from Rutgers University where Dr. Lisa C Klein advised his dissertation. Dr. Brinker is currently Sandia National Laboratory Fellow and Distinguished and Regent's Professor at the University of New Mexico with joint appointments in the Departments of Chemical and Biological Engineering, Molecular Genetics and Microbiology, and the UNM Comprehensive Cancer Center.

Dr. C Jeffrey Brinker pioneered the so-called "sol-gel processing" as a means of solution-based synthesis of a wide range of inorganic and composite nanostructured materials. During the past two decades, by combining solgel processing with molecular self-assembly, he developed robust "evaporation-induced self-assembly" procedures,

Table 1 The list of the recipients of the Life Achievement Award

\begin{tabular}{lll}
\hline Year & Name of the awardee(s) & $\begin{array}{l}\text { Place of the Sol-gel } \\
\text { Conference }\end{array}$ \\
\hline 2005 & $\begin{array}{l}\text { Helmuth Schmidt } \\
2007\end{array}$ & $\begin{array}{l}\text { Jacques Livage and Sumio } \\
\text { Sakka }\end{array}$ \\
2009 & $\begin{array}{l}\text { Doug Mackenzie } \\
\text { Montpellier, France }\end{array}$ \\
2011 & $\begin{array}{l}\text { Tsutomu Minami and Michel A } \\
\text { Aegerter }\end{array}$ & $\begin{array}{l}\text { Porto de Galinhas, Brazil } \\
\text { Hangzhou, China }\end{array}$ \\
2013 & $\begin{array}{l}\text { David Avnir } \\
\text { Clement Sanchez } \\
2015\end{array}$ & $\begin{array}{l}\text { Madrid, Spain } \\
\text { Kyoto, Japan }\end{array}$ \\
2017 & $\begin{array}{l}\text { Lisa C Klein and C Jeffrey } \\
\text { Brinker }\end{array}$ & Liege, Belgium \\
\end{tabular}

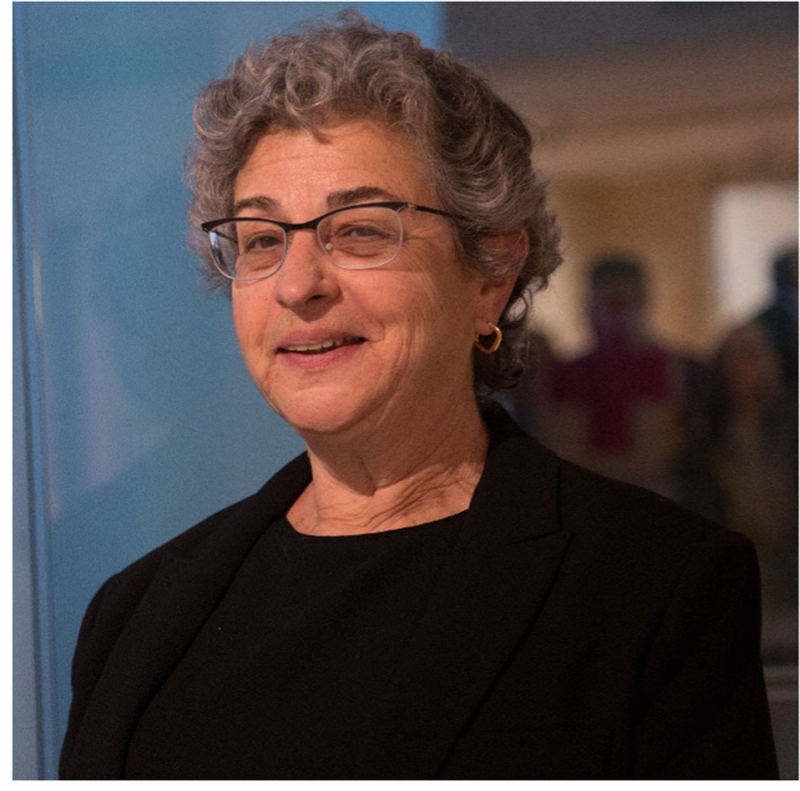

Fig. 1 Dr. Lisa C Klein the 2017 Life Achievement awardee

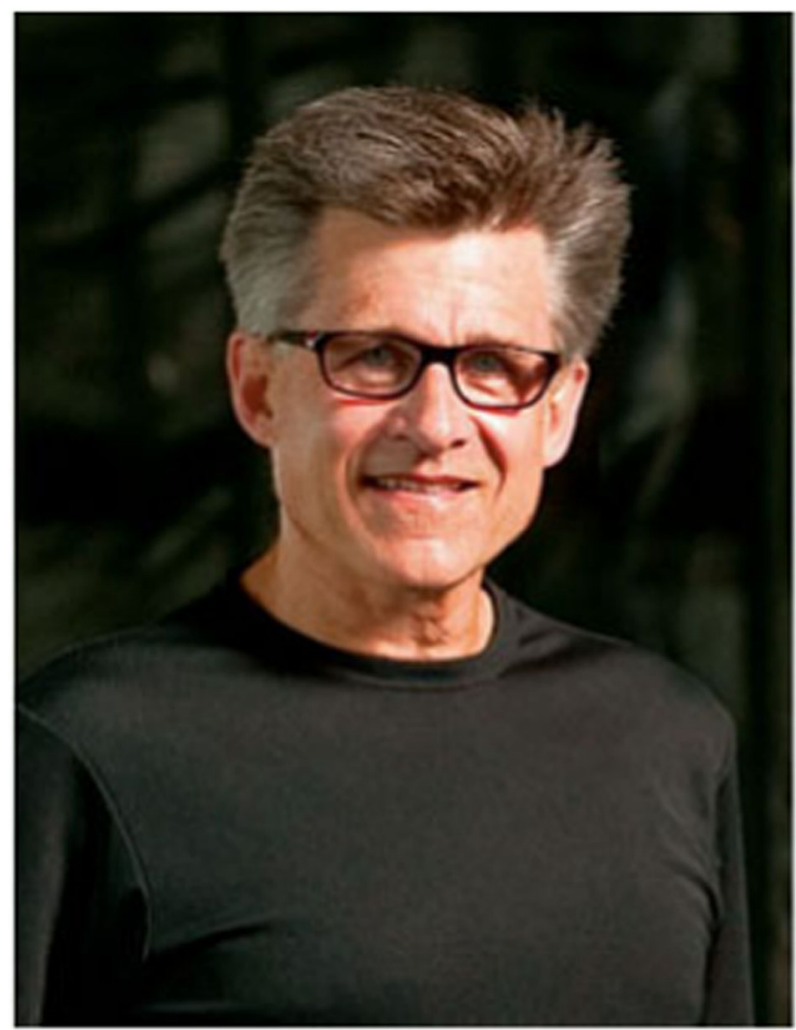

Fig. 2 Dr. C Jeffrey Brinker the 2017 Life Achievement awardee

enabling the facile synthesis of highly ordered porous and composite nanostructured films and particles. His team was the first that reported the development of the "protocell" - a nanoporous silica nanoparticle loaded with drugs/imaging agents and encapsulated within a protective and 


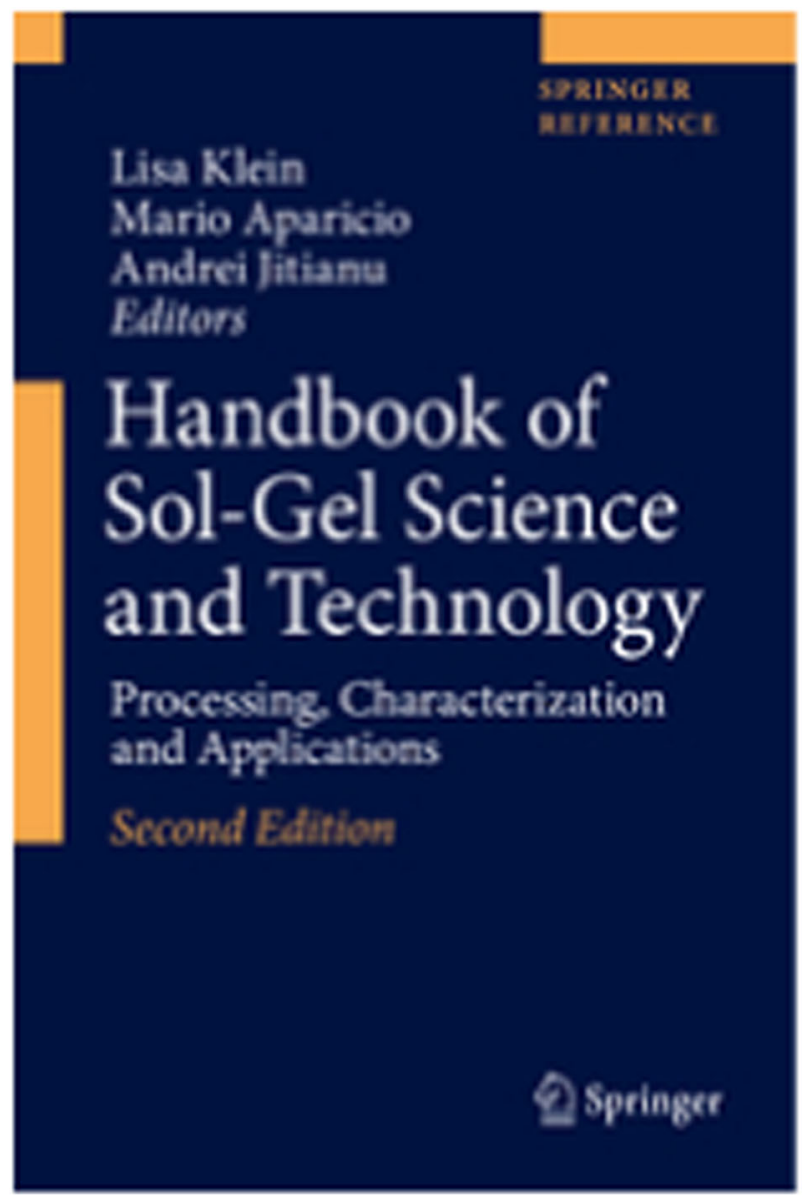

Fig. 3 The cover of the Handbook "Handbook of Sol-Gel Science and Technology Processing Characterization and Applications" [1]

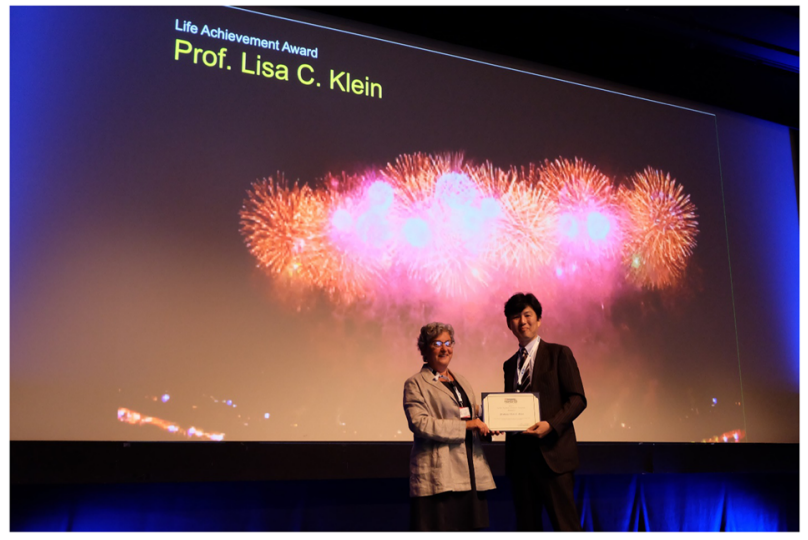

Fig. 4 Dr. Lisa C Klein receiving the 2017 Life Achievement Award from Dr. Masahide Takahashi, President of the International Sol-Gel Society

biocompatible supported lipid bilayer-as a universal, modular, nanocarrier platform for passive or active targeted delivery of multicomponent cargos to cancer.

The first fundamental and systematic studies of chemistry and physics of the processing of ceramics via sol-gel

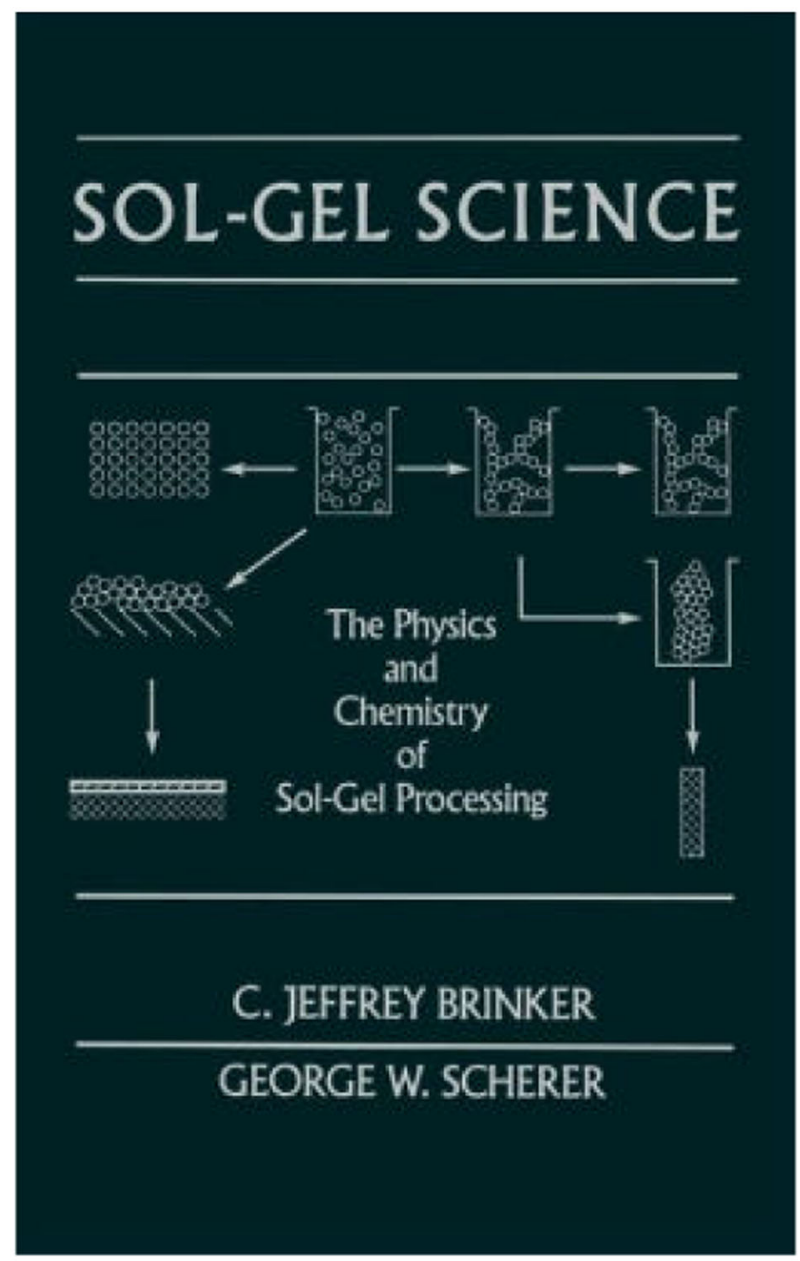

Fig. 5 The cover of the Sol-Gel Science-the Physics and Chemistry of Sol-Gel Processing

method was co-authored by Dr. Brinker and published in 1990 as "Sol-Gel Science - the Physics and Chemistry of Sol-Gel Processing" [2] (Fig. 5). This book is still considered to be the "Bible" of the Sol-Gel Science and Technology.

Here are some highlights of Professor Brinker's career:

- 2017-Life Achievement Award of the ISGS, Liege, Belgium (Fig. 5).

- 2015-Elected to the US National Academy of Inventors.

- 2015-University of New Mexico STC, Innovation Fellow Award.

- 2015-R\&D 100's 'Green Technology Special Recognition Gold Award' for CO Memzyme.

- 2015-UNM Presidential Medal of Distinction.

- 2012-Médaille du Collège de France, Paris.

- 2011-R\&D 100 Award Biomimetic Water Purification Membranes. 
- 2010-Robert B Sosman Award, American Ceramic Society.

- 2009-Fellow of the Materials Research Society.

- 2008-Edward R Orton Jr Memorial Award, American Ceramic Society and ASM.

- 2007-R\&D 100 Award: Self-Assembling Process for Fabricating Tailored Thin Films.

- 2006-Rutgers University Distinguished Alumnus Award.

- 2003-Materials Research Society MRS Medal.

- 2002-DOE Ernest O Lawrence Memorial Award in Materials Science.

- 2002-Elected to the National Academy of Engineering.

- 1996-American Chemical Society Ralph K Iler Award in the Chemistry of Colloidal Materials.

- 1988-WH Zachariasen Award for best contribution to the glass literature 1985-1987, awarded by the Journal of Non-Crystalline Solids.

On September 7, 2017, the Life Achievement Award was presented to Dr. Brinker in a ceremony (Fig. 6) which took place during The XIX International Sol-Gel Conference hold in Liege, Belgium, September 3-8, 2017. The awardee presented a plenary lecture entitled: "Sol-Gel Enabled Drug Delivery and gene editing using mesoporous silica nanoparticles encapsulated within supported lipid bilayers aka Protocells." His contribution entitled "Engineering of Large-Pore Lipid-Coated Mesoporous Silica Nanoparticles for Dual Cargo Delivery to Cancer Cells" can be found in this special issue.

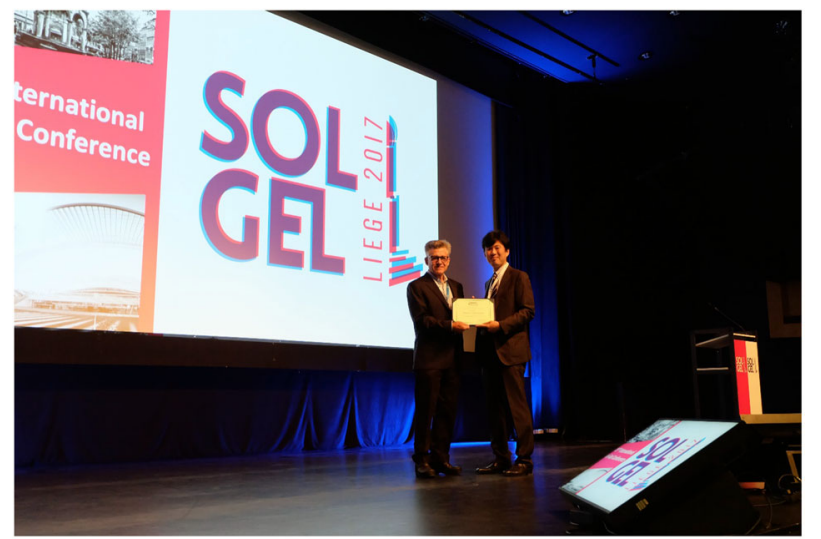

Fig. 6 Dr. C Jeffrey Brinker receiving the 2017 Life Achievement Award from Dr Masahide Takahashi, President of the International Sol-Gel Society

Publisher's note: Springer Nature remains neutral with regard to jurisdictional claims in published maps and institutional affiliations.

\section{References}

1. Klein LC, Aparicio M, Jitianu A (2018) Handbook of sol-gel science and technology; processing characterization and applications, 2nd edn. Springer, New York

2. Brinker CJ, Scherer GW (1990) Sol-gel science: the physics and chemistry of sol-gel processing. Academic Press, San Diego 